\title{
The role of interleukin-18 in the metabolic syndrome
}

\author{
Marius Trøseid ${ }^{1 *}$, Ingebjørg Seljeflot ${ }^{1,2}$, Harald Arnesen ${ }^{1,2}$
}

\begin{abstract}
The metabolic syndrome is thought to be associated with a chronic low-grade inflammation, and a growing body of evidence suggests that interleukin-18 (IL-18) might be closely related to the metabolic syndrome and its consequences. Circulating levels of IL-18 have been reported to be elevated in subjects with the metabolic syndrome, to be closely associated with the components of the syndrome, to predict cardiovascular events and mortality in populations with the metabolic syndrome and to precede the development of type 2 diabetes. IL-18 is found in the unstable atherosclerotic plaque, in adipose tissue and in muscle tissue, and is subject to several regulatory steps including cleavage by caspase-1, inactivation by IL-18 binding protein and the influence of other cytokines in modulating its interaction with the IL-18 receptor. The purpose of this review is to outline the role of IL-18 in the metabolic syndrome, with particular emphasis on cardiovascular risk and the potential effect of life style interventions.
\end{abstract}

\section{Introduction}

The metabolic syndrome is a cluster of risk factors that identifies a population with increased risk for developing type 2 diabetes mellitus and cardiovascular disease (CVD). The syndrome has received increased attention after practical definitions by the Adult Treatment Panel III and International Diabetes Federation [1,2]. The diagnostic criteria vary slightly, in particular concerning the meausure for central obesity, but in a recent statement it is agreed that the presence of any three of the following five components is diagnostic for the metabolic syndrome: Central obesity, elevated blood pressure, raised fasting glucose, raised levels of trigycerides and low levels of high-density lipoprotein cholesterol [3]. More than 25\% of the US population can be classified as having the metabolic syndrome, and the prevalence is increasing with age, affecting $>40 \%$ of US adults above the age of 60 years [4-6].

The metabolic syndrome is a strong predictor of type 2 diabetes, with an increased incidence rate of 5 to 7 -fold $[7,8]$. Indeed, the increased cardiovascular risk might develop as a continuum in parallel with increasing fasting glucose, from the normal range via impaired fasting glucose to overt diabetes mellitus [9]. The risk of

\footnotetext{
* Correspondence: troseid@hotmail.com

${ }^{1}$ Center for Clinical Heart Research, Department of Cardiology, Oslo University Hospital, Ullevål, Oslo, Norway
}

developing CVD is approximately doubled in the metabolic syndrome [10]. In a meta-analysis including 43 cohorts, the relative risk for cardiovascular events and death was 1.78, with the highest risk in women [11].

There is increasing evidence that the metabolic syndrome is associated with a chronic, low-grade inflammation [2]. Several pro-inflammatory cytokines have been shown to be elevated in parallel with an increasing number of components of the syndrome, whereas the anti-inflammatory and adipocyte-specific substance adiponectin is consistently lower [12-15]. Some investigators have discussed that both type 2 diabetes, metabolic syndrome and atherosclerosis are multifactorial conditions which appear to have a common inflammatory basis [16], and it is currently discussed if a measure of inflammation should be included in the definition of the syndrome [2,17]. So far, CRP has been the most likely candidate $[17,18]$.

However, a growing body of evidence suggests that IL18 is closely associated with the metabolic syndrome and its consequences. The purpose of this review is to outline the role of IL-18 in the metabolic syndrome, with particular emphasis on CVD risk and life style interventions.

\section{Interleukin-18: a unique proinflammatory cytokine}

IL-18 is a member of the IL-1 family of cytokines and was originally described as an interferon gamma (IFN- $\gamma$ ) 
inducing factor [19]. The cytokine is produced constitutively in many different cell types, including macrophages, endothelial cells, vascular smooth muscle cells, dendritic cells and Kupffer cells [20-22]. IL-18 is also produced in adipocytes [23], but non-adipocyte cells have been identified as the main source of IL-18 in adipose tissue [24]. In contrast to most other cytokines, but in a similar way to IL- $1 \beta$, IL-18 is expressed as a precursor, pro-IL18, which is inactive until cleaved by the enzyme caspase-1 [25]. Notably, caspase-1 itself exists as an inactive precursor which requires the assembly of multi-unit complexes, known as inflammasomes, to be activated $[26,27]$.

Once secreted, IL-18 is bound and inactivated by IL18 binding protein, which is enhanced as a negative feedback mechanism in response to increased IL-18 production, ensuring protection from tissue damage due to uncontrolled proinflammatory activity $[28,29]$. IL-18 binds to its receptor, consisting of an $\alpha$ chain which is responsible for extracellular binding of IL-18, and a $\beta$ chain which is responsible for intracellular signal transduction $[25,30,31]$. Although both free and proteinbound IL-18 may bind to the $\alpha$ chain, only the free fraction is able to activate the $\beta$ chain $[28,29]$.

IL-18 is a potent proinflammatory cytokine which enhances $\mathrm{T}$ cell and natural killer cell maturation, as well as the production of cytokines, chemokines and cell adhesion molecules $[32,33]$. Of note, in CD4+ lymphocytes IL-18 can stimulate both type 1 helper T (Th1) and Th2 responses depending on its cytokine milieu: IL18 may stimulate a Th2 response in combination with IL-2, and may act synergistically with IL-12 to stimulate a Th1 response with production of IFN- $\gamma$ [25], a central feature in the atherosclerotic lesion (Figure 1). One mechanism underlying this synergistic effect is that IL12 may induce the $\alpha$ chain of the IL-18 receptor in lymphocytes [34,35], whereas in non- $T$ cells such as macrophages, the IL-18 receptor is constitutively expressed.

\section{Interleukin-18 in the metabolic syndrome and type 2 diabetes}

IL-18 has in several studies been associated with obesity [14,36-38], insulin resistance [39-41], hypertension [42] and dyslipidemia [14,37]. Furthermore, IL-18 has been shown to be elevated in subjects with the metabolic syndrome [43] and to increase in parallell with an increasing number of components of the syndrome [38]. In a large cross sectional study, elevated IL-18 levels were associated with increasing number of components also after adjustment for insulin resistance, obesity, IL- 6 and CRP [14]. Polymorphisms in the IL-18 gene have been shown to be associated with circulating IL-18 levels [44]. Interestingly, a recent study showed that one such polymorphism was associated with increased serum levels of IL-18, impaired insulin sensitivity and increased risk of having the metabolic syndrome [45], suggesting that IL-18 might be involved in the pathogenesis of the syndrome.

Circulating levels of IL-18 have consistently been reported to be elevated in patients with type 2 diabetes mellitus in cross sectional studies [40,46,47], and have also been suggested to contribute to microangiopathy such as nephropathy in type 2 diabetes [48]. Moreover, in two prospective cohorts, elevated levels of IL-18 have been shown to predict the development of type 2 diabetes (Table 1) [49,50]. However, a major limitation of both studies is that fasting glucose or oral glucose tolerance tests were not performed at baseline evaluation: Elevated fasting glucose increases the risk of diabetes, and experimental hyperglycemia might increase circulating levels of IL-18 [51].

\section{Interleukin-18 and cardiovascular disease}

Studies regarding assocations between IL-18 and stable atherosclerosis have yielded conflicting results. One study showed that elevated levels of IL-18 were associated with the presence of subclinical atherosclerosis evaluated with intima media thickness of the carotid artery, also after adjustment for traditional risk factors, CRP and IL-6 [52]. On the other hand, in two large studies elevated levels of IL-18 were associated with carotid intima media thickness in univariate analyses, but not after adjustment for traditional risk factors $[38,53]$. Furthermore, in a study of patients with type 2 diabetes, both carotid intima media thickness and brachial-ankle pulse wave velocity were significantly associated with serum levels of IL-18, although not in multivariate analyses [54]. However, we recently showed that arterial stiffness measured by brachial pulse wave propagation was associated with IL-18 levels and components of the metabolic syndrome, even in multivariate analyses, both cross sectionally and during three years follow up [55].

Also data regarding IL-18 as a potential predictor of future cardiovascular events have so far been conflicting (Table 1). In patients with known coronary artery disease, circulating IL-18 levels as well as polymorphisms in the IL-18 gene were associated with future cardiovascular mortality $[56,57]$. In two prospective studies, elevated IL-18 levels were associated with future cardiovascular disease in previously healthy men [58] and women [59]. However, another large population based study with a follow up of 11 years showed that increased levels of IL- 6 and CRP, but not IL-18 were associated with future coronary events [60]. Furthermore, a recent study from five European prospective CVD cohorts showed no association between polymorphisms in the IL-18 receptor genes and cardiovascular risk [61]. 


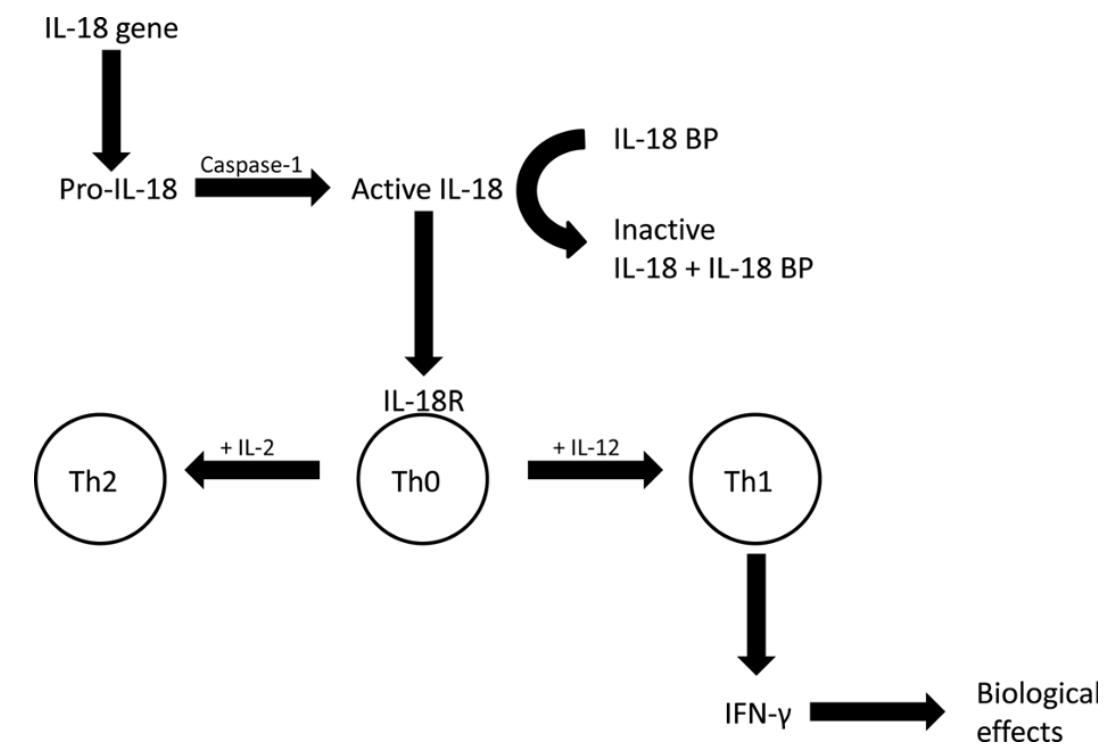

Figure 1 Regulation and biological effects of interleukin-18. The cytokine is expressed as a precursor, pro-IL-18, which is inactive until cleaved by caspase-1. Once secreted, IL-18 is bound and inactivated by IL-18 binding protein (IL-18 BP), and only the free fraction can stimulate a signal transduction via the $\beta$-chain of the IL-18 receptor (IL-18R). The biological effect is dependent on the cytokine milieu: IL-18 may stimulate a Th2 response in combination with IL-2, and may act synergistically with IL-12 to stimulate a Th1 response with production of IFN- $\gamma$, a central feature of the atherosclerotic lesion.

Table 1 Prospective studies evaluating the effect of elevated circulating IL-18 levels on cardiovascular, metabolic syndrome and diabetes related end points.

\begin{tabular}{|c|c|c|c|c|}
\hline Study & Patients (n) and study population & $\begin{array}{l}\text { Follow-up, } \\
\text { years }\end{array}$ & End points & Outcome \\
\hline Blankenberg et al. [56] & $\begin{array}{l}1229 \\
\text { (known CAD) }\end{array}$ & 4 & $\begin{array}{l}\text { Cardiovascular } \\
\text { mortality }\end{array}$ & $\begin{array}{l}\text { Increased risk of cardiovascular } \\
\text { mortality }\end{array}$ \\
\hline Blankenberg et al. [58] & $\begin{array}{l}335 \text { cases and } 670 \text { controls } \\
\text { (healthy men) }\end{array}$ & 5 & CAD & Increased risk of CAD \\
\hline Everett et al. [59] & $\begin{array}{l}253 \text { cases and } 253 \text { controls } \\
\text { (healthy women) }\end{array}$ & 6 & CVD & Increased risk of CVD \\
\hline Koenig et al. [60] & $\begin{array}{l}382 \text { cases and } 1980 \text { controls } \\
\text { (population based) }\end{array}$ & 11 & CAD & No increased risk of CAD \\
\hline Espinola-Klein et al. [62] & $\begin{array}{l}\text { 1263, stratified for MS } \\
\text { (known CAD) }\end{array}$ & 6 & $\begin{array}{l}\text { Cardiovascular } \\
\text { mortality }\end{array}$ & $\begin{array}{l}\text { Increased risk of cardiovascular } \\
\text { mortality in MS strata }\end{array}$ \\
\hline Trøseid et al. [63] & $\begin{array}{l}563 \text {, stratified for MS (elderly high } \\
\text { risk men) }\end{array}$ & 3 & CVD & Increased risk of CVD in MS strata \\
\hline Thorand et al. [50] & $\begin{array}{l}527 \text { cases and } 1698 \text { controls } \\
\text { (population based) }\end{array}$ & 11 & Type 2 diabetes & Increased risk of type 2 diabetes \\
\hline Hivert et al. [49] & $\begin{array}{l}1012 \text { cases and } 1081 \text { controls } \\
\text { (women) }\end{array}$ & 12 & Type 2 diabetes & Increased risk of type 2 diabetes \\
\hline
\end{tabular}

CAD; coronary artery disease, CVD; cardiovascular disease, MS; metabolic syndrome.

To date, only two studies have prospectively evaluated IL-18 as a potential predictor of cardiovascular events in populations with the metabolic syndrome (Table 1). In a large cohort consisting of men and women with known coronary artery disease, IL-18 was the only independent predictor of cardiovascular mortality in a subgroup with the metabolic syndrome, even after adjustment for CRP, IL-6 and fibrinogen [62]. In line with these results, we showed that IL-18 was a strong and independent predictor of cardiovascular events in elderly men with the metabolic syndrome, also after adjustment for CRP and IL-6, and with a synergistic effect of IL-18 and fasting glucose in the cardiovascular risk prediction [63].

\section{Potential mechanisms for interleukin-18 in the metabolic syndrome and atherosclerosis Interleukin-18 in atherosclerotic lesions}

IL-18 has been shown to be highly expressed in atherosclerotic plaques, mainly in plaque macrophages, and in particular in unstable plaques [64]. IL-18 is thought to 
exert its main pro-atherogenic effects by inducing IFN- $\gamma$ production, which potentiates the inflammatory process and may lead to thinning or inhibition of the fibrous cap formation, resulting in vulnerable, rupture-prone plaques $[65,66]$. Furthermore, IL-18 seems to increase the expression of matrix metalloproteinases in vascular cells and macrophages, which might also contribute to plaque destabilisation $[22,65]$.

Indeed, IL-18 might also directly cause plaque destabilisation and cardiac dysfunction. In a model with Apo E deficient mice, IL-18 overexpression enhanced the collagenolytic activity of smooth muscle cells, reduced intimal collagen content and fibrous cap thickness, leading to vulnerable plaque morphology [67]. Furthermore, in a mouse model with myocardial infarction, increased expression of cardiac IL-18 mRNA and a subsequent reduction of myocardial contractility were reported [68]. Interestingly, in a rat model with the metabolic syndrome, IL-18 overexpression aggravated insulin resistance, increased vascular inflammation and promoted remodeling by enhanced infiltration of macrophages and increased medial thickness in the aortic wall [69].

\section{Interleukin-18 in adipose tissue}

The classical perception of adipose tissue as a passive storage place of fatty acids has gradually been replaced by the notion of adipose tissue, and visceral fat in particular as an active endocrine organ. Visceral fat is now considered a central feature and potential cause of the metabolic syndrome [70], in part mediated by release of a large number of metabolically active substances known as adipokines. Adipokines are involved in several biological processes, including inflammation, thrombosis, insulin sensitivity and energy balance [71].

Human preadipocytes and adipocytes of all stages have been shown to spontaneously express and secrete IL-18 $[23,72]$. Of note, in obese individuals there is an increased expression of IL-18 in adipose tissue [36], and a 3-fold increased secretion from adipocytes compared with lean controls [23]. Interestingly, experimental hyperglycemia has been shown to increase the expression of IL-18 in adipocytes, an effect which was even more pronounced in the presence of intermittent hyperglycemia [73]. However, other studies have reported that non-adipocytes are the main sources of IL-18 in adipose tissue [24].

Whereas previous studies have reported macrophage infiltration in adipose tissue in obesity and insulin resistance [74,75], a recent study showed that infiltration of T-lymphocytes preceded the infiltration of macrophages in adipose tissue in early stages of insulin resistance in obese mice [76]. Notably, in human patients with type 2 diabetes from the same report, waist circumference correlated significantly with expression of IFN- $\gamma$ in adipose tissue, suggesting a role of Th1 cells in insulin resistance
[76]. Moreover, in another study of obese mice, there was a clear bias towards Th1 polarisation of lymphocytes in adipose tissue, which was associated with insulin resistance and could be reversed by immunotherapy [77]. IL-18 acts in synergy with IL-12 to stimulate Th1 polarisation [25], and levels of IL-12 have been reported to be increased in subjects with type 2 diabetes and by experimental hyperglycemia $[78,79]$. Hence, it could be speculated that IL-18 in combination with a hyperglycemic proinflammatory milieu might trigger Th1 activation and IFN- $\gamma$ production [63], both in adipose tissue and in the atherosclerotic plaque.

\section{Interleukin-18 in muscle tissue}

Several reports have suggested that adipose tissue might not be the main source of IL-18 in patients with obesity and the metabolic syndrome $[36,49,80,81]$. In one study, plasma levels of IL-18 were reduced by weight loss, whereas no effect was seen on adipose tissue expression of IL-18 [36]. In another study, we showed that the reduction of IL-18 levels by exercise was significantly associated with improvement of the metabolic syndrome, but not with a reduction in visceral fat [81]. Hence, other body compartments might be involved.

There is increasing evidence that cytokines are involved in the regulation of skeletal muscle function, and tumor necrosis factor- $\alpha$ (TNF- $\alpha$ ) has been associated with muscle catabolism and loss of muscle function [82]. IL-18 expression has been demonstrated in human skeletal muscles in a fiber specific way both in healthy individuals [83] and in patients with myopathy [67].

Recently, it was shown experimentally that TNF- $\alpha$ infusion induced reduced glucose uptake and increased IL-18 expression in human skeletal muscle tissue but not in adipose tissue, and the authors suggest that adipose tissue is unlikely to be a major source of IL-18 [80]. Still, it remains to demonstrate whether muscle tissue could be a major source of circulating IL-18 in subjects with and without the metabolic syndrome.

\section{Interleukin-18 resistance}

Paradoxically, genetically modified mice with IL-18 deficiency have been reported to develop hyperphagia, obesity and insulin resistance, which might be reversed by recombinant IL-18 administration [84]. Furthermore, it was shown that patients with obesity and type 2 diabetes produce significantly less IFN- $\gamma$ in peripheral blood mononuclear cells in response to IL-18 stimulation compared to lean controls, most likely due to reduced expression of the IL-18 receptor $\beta$ chain, and the authors have introduced a consept of IL-18 resistance as a potential explanation of elevated IL-18 levels in such patients [85]. This observation is supported by several studies that report defect leucocyte function and increased susceptibility to infections in patients with 
type 2 diabetes [86-88]. However, it remains to determine whether this immunological phenomenon translates into a similar resistance to the metabolic effects of IL-18 [85], and which organs that might be involved in such a process.

\section{Interleukin-18 as a potential therapeutic target Effects of life style interventions}

Lifestyle interventions consisting of diet and exercise have been shown to improve several cardiovascular risk factors including the metabolic syndrome and to reduce the risk of developing type 2 diabetes [89,90]. Hence, current guidelines for management of the metabolic syndrome highlight the combination of increased physical activity (at least 30 minutes on most days of the week) and improved diet (decreased intake of saturated fat and simple carbohydrates, increased intake of fruits, vegetables, whole grain and fish) to achieve a sustained weight loss and reversal of the components of the syndrome [2].

Weight loss mediated by calorie-restricted diet intervention was reported to decrease IL-18 levels in obese women [91]. Furthermore, combined interventions with diet and exercise have been shown to reduce IL-18 levels in both obese men [36] and women [92]. We have reported reduced serum levels of IL-18 by Mediterranean-like diet and omega-3 fatty acid supplementation in a popluation of elderly high-risk men [93]. In a post hoc analysis from the same trial, the reduction of IL-18 levels was associated with an increased number of metabolic syndrome components that improved during three years of intervention [55]. Moreover, Mediterranean-like diet was shown to reduce levels of CRP, IL-6 and IL-18 in a middle-aged population with the metabolic syndrome [94].

Aerobic exercise has been reported to reduce levels of CRP and IL-18 in subjects with type 2 diabetes $[95,96]$. In another study, aerobic exercise, but not strength training, reduced circulating levels of CRP, IL- 6 and IL18 in older subjects [97]. On the other hand, both endurance training and strength training reduced plasma levels of IL-18 in a cohort of HIV-infected patients with lipodystrophy $[23,98]$. Furthermore, exercise performed on rowing ergometer reduced adipose tissue expression of IL-18 in obese subjects [99]. Moreover, in a middle aged cohort of men with the metabolic syndrome, we have reported reduced levels of IL-18 associated with improvement of metabolic syndrome components by a combined intervention consisting of aerobic exercise and strength training [81].

\section{Effects of drug therapy}

Several drugs are relevant in the management of the metabolic syndrome, but this review will focus on the most commonly used first line drugs recommended in current guidelines [2], i.e. statins and Angiotensin Converting Enzyme (ACE)-inhibitors/Angiotensin II (ATII) receptor antagonists.

The effects of statin therapy on IL-18 levels have been conflicting. Some studies have shown reduced circulating levels of IL-18 in statin treated patients with hypercholesterolemia [100,101]. Furthermore, we showed a tendency to additive effect of exercise and pravastatin on serum levels of IL-18 in subjects with the metabolic syndrome [81]. On the other hand, one study showed no effect of 20 months treatment with atorvastatin in patients with stable coronary artery disease [102]. Moreover, statin therapy has consistently been reported to increase IL-18 in peripheral mononuclear cells [103-105]. Hence, the effect of statins on IL-18 levels remains elusive.

Although ACE-inhibitors and ATII receptor antagonists have been reported to have several anti-inflammatory properties, very few studies have evaluated the effect of these compounds on IL-18 levels. In experimental studies, ATII has been shown to increase IL-18 expression in vascular smooth muscle cells [106], whereas ATII receptor antagonists could inhibit aldosteron-induced IL-18 expression in cardiomyocytes [107]. However, candesartan treatment had no effect on circulating levels of IL-18 in patients with stable heart failure [108].

\section{Conclusions and future perspectives}

Several lines of evidence support a pivotal role of IL-18 in the pathogenesis of the metabolic syndrome. Importantly, IL-18 has been shown to be closely associated with the metabolic syndrome and its components [14], to predict cardiovascular events and cardiovascular mortality in populations with the metabolic syndrome $[62,63]$, and to precede the development of diabetes [49]. Still, the exact role of IL-18 in these conditions needs to be clarified.

Although life style interventions such as diet and exercise have been shown to reduce levels of IL-18 in populations with and without the metabolic syndrome, it remains to demonstrate that such a reduction translates into reduced incidence of diabetes and cardiovascular events. Furthermore, the contribution of adipose tissue, muscle tissue and other organs in regulating circulating levels of IL-18, as well as the potential role of IL-18 resistance require further investigation.

Since IL-18 is subject to several regulatory steps including cleavage by caspase- 1 , inactivation by IL- 18 binding protein, and signalling via the $\beta$ chain of the IL18 receptor, it will be crucial to clarify to what extent circulating levels of total IL-18 relate to the biological actions of the cytokine. Finally, strategies for blocking IL-18 activity are currently investigated in various 
pathophysological conditions such as sepsis and heart failure [109], and could potentially represent future therapeutic tools for the metabolic syndrome and its consequences.

\section{Author details}

${ }^{1}$ Center for Clinical Heart Research, Department of Cardiology, Oslo University Hospital, Ullevål, Oslo, Norway. ${ }^{2}$ Faculty of Medicine, University of Oslo, Oslo, Norway.

\section{Authors' contributions}

MT drafted the manuscript. IS and HA critically reviewed the manuscript. All authors read and approved the final manuscript.

\section{Competing interests}

The authors declare that they have no competing interests.

Received: 14 February 2010 Accepted: 23 March 2010

Published: 23 March 2010

\section{References}

1. Alberti KG, Zimmet P, Shaw J: The metabolic syndrome-a new worldwide definition. Lancet 2005, 366:1059-1062.

2. Grundy SM, Cleeman II, Daniels SR, Donato KA, Eckel RH, Franklin BA, et al: Diagnosis and management of the metabolic syndrome: an American Heart Association/National Heart, Lung, and Blood Institute Scientific Statement. Circulation 2005, 112:2735-2752.

3. Alberti KG, Eckel RH, Grundy SM, Zimmet PZ, Cleeman JI, Donato KA, et al: Harmonizing the metabolic syndrome: a joint interim statement of the International Diabetes Federation Task Force on Epidemiology and Prevention; National Heart, Lung, and Blood Institute; American Heart Association; World Heart Federation; International Atherosclerosis Society; and International Association for the Study of Obesity. Circulation 2009, 120:1640-1645.

4. Ford ES, Giles WH, Dietz WH: Prevalence of the metabolic syndrome among US adults: findings from the third National Health and Nutrition Examination Survey. JAMA 2002, 287:356-359.

5. Ford ES, Giles WH, Mokdad AH: Increasing prevalence of the metabolic syndrome among u.s. Adults. Diabetes Care 2004, 27:2444-2449.

6. Li C, Ford ES, MCGuire LC, Mokdad AH: Increasing trends in waist circumference and abdominal obesity among US adults. Obesity (Silver Spring) 2007, 15:216-224.

7. Eckel RH, Grundy SM, Zimmet PZ: The metabolic syndrome. Lancet 2005, 365:1415-1428.

8. Wilson PW, D'Agostino RB, Parise H, Sullivan L, Meigs JB: Metabolic syndrome as a precursor of cardiovascular disease and type 2 diabetes mellitus. Circulation 2005, 112:3066-3072.

9. Haffner SM, Stern MP, Hazuda HP, Mitchell BD, Patterson JK: Cardiovascular risk factors in confirmed prediabetic individuals. Does the clock for coronary heart disease start ticking before the onset of clinical diabetes? JAMA 1990, 263:2893-2898.

10. Grundy SM: Metabolic syndrome pandemic. Arterioscler Thromb Vasc Biol 2008, 28:629-636.

11. Gami AS, Witt BJ, Howard DE, Erwin PJ, Gami LA, Somers VK, et at: Metabolic syndrome and risk of incident cardiovascular events and death: a systematic review and meta-analysis of longitudinal studies. J Am Coll Cardiol 2007, 49:403-414.

12. Kowalska I, Straczkowski M, Nikolajuk A, Adamska A, KarczewskaKupczewska M, Otziomek E, et al: Insulin resistance, serum adiponectin, and proinflammatory markers in young subjects with the metabolic syndrome. Metabolism 2008, 57:1539-1544.

13. Pradhan A: Obesity, metabolic syndrome, and type 2 diabetes: inflammatory basis of glucose metabolic disorders. Nutr Rev 2007, 65:S152-S156.

14. Hung J, McQuillan BM, Chapman CM, Thompson PL, Beilby JP: Elevated interleukin-18 levels are associated with the metabolic syndrome independent of obesity and insulin resistance. Arterioscler Thromb Vasc Biol 2005, 25:1268-1273.

15. Hung J, McQuillan BM, Thompson PL, Beilby JP: Circulating adiponectin levels associate with inflammatory markers, insulin resistance and metabolic syndrome independent of obesity. Int J Obes (Lond) 2008, 32:772-779.

16. Pradhan AD, Ridker PM: Do atherosclerosis and type 2 diabetes share a common inflammatory basis? Eur Heart J 2002, 23:831-834.

17. Haffner SM: The metabolic syndrome: inflammation, diabetes mellitus, and cardiovascular disease. Am J Cardiol 2006, 97:3A-11A.

18. Ridker PM, Wilson PW, Grundy SM: Should C-reactive protein be added to metabolic syndrome and to assessment of global cardiovascular risk? Circulation 2004, 109:2818-2825.

19. Okamura H, Tsutsi H, Komatsu T, Yutsudo M, Hakura A, Tanimoto T, et al: Cloning of a new cytokine that induces IFN-gamma production by $\mathrm{T}$ cells. Nature 1995, 378:88-91.

20. Dinarello CA: The IL-1 family and inflammatory diseases. Clin Exp Rheumatol 2002, 20:S1-13.

21. Dinarello CA: Interleukin-18 and the pathogenesis of inflammatory diseases. Semin Nephrol 2007, 27:98-114.

22. Gerdes N, Sukhova GK, Libby P, Reynolds RS, Young JL, Schonbeck U: Expression of interleukin (IL)-18 and functional IL-18 receptor on human vascular endothelial cells, smooth muscle cells, and macrophages: implications for atherogenesis. J Exp Med 2002, 195:245-257.

23. Skurk T, Kolb H, Muller-Scholze S, Rohrig K, Hauner H, Herder C: The proatherogenic cytokine interleukin-18 is secreted by human adipocytes. Eur J Endocrinol 2005, 152:863-868.

24. Fain JN, Tichansky DS, Madan AK: Most of the interleukin 1 receptor antagonist, cathepsin $\mathrm{S}$, macrophage migration inhibitory factor, nerve growth factor, and interleukin 18 release by explants of human adipose tissue is by the non-fat cells, not by the adipocytes. Metabolism 2006, 55:1113-1121.

25. Nakanishi K, Yoshimoto T, Tsutsui H, Okamura H: Interleukin-18 is a unique cytokine that stimulates both Th1 and Th2 responses depending on its cytokine milieu. Cytokine Growth Factor Rev 2001, 12:53-72.

26. Shaw MH, Reimer T, Kim YG, Nunez G: NOD-like receptors (NLRs): bona fide intracellular microbial sensors. Curr Opin Immunol 2008, 20:377-382.

27. Sirard JC, Vignal C, Dessein R, Chamaillard M: Nod-like receptors: cytosolic watchdogs for immunity against pathogens. PLoS Pathog 2007, 3:e152.

28. Novick D, Kim SH, Fantuzzi G, Reznikov LL, Dinarello CA, Rubinstein M: Interleukin-18 binding protein: a novel modulator of the Th1 cytokine response. Immunity 1999, 10:127-136.

29. Novick D, Schwartsburd B, Pinkus R, Suissa D, Belzer I, Sthoeger Z, et al: A novel IL-18BP ELISA shows elevated serum IL-18BP in sepsis and extensive decrease of free IL-18. Cytokine 2001, 14:334-342.

30. Kato Z, Jee J, Shikano H, Mishima M, Ohki I, Ohnishi H, et al: The structure and binding mode of interleukin-18. Nat Struct Biol 2003, 10:966-971.

31. Torigoe K, Ushio S, Okura T, Kobayashi S, Taniai M, Kunikata T, et al: Purification and characterization of the human interleukin-18 receptor. J Biol Chem 1997, 272:25737-25742.

32. Dinarello CA: Interleukin 1 and interleukin 18 as mediators of inflammation and the aging process. Am J Clin Nutr 2006, 83:447S-455S.

33. Gracie JA, Robertson SE, McInnes IB: Interleukin-18. J Leukoc Biol 2003, 73:213-224.

34. Ahn HJ, Maruo S, Tomura M, Mu J, Hamaoka T, Nakanishi K, et al: A mechanism underlying synergy between IL-12 and IFN-gammainducing factor in enhanced production of IFN-gamma. J Immunol 1997, 159:2125-2131.

35. Yoshimoto T, Takeda K, Tanaka T, Ohkusu K, Kashiwamura S, Okamura H, et al: IL-12 up-regulates IL-18 receptor expression on T cells, Th1 cells, and B cells: synergism with IL-18 for IFN-gamma production. J Immunol 1998, 161:3400-3407.

36. Bruun JM, Stallknecht B, Helge JW, Richelsen B: Interleukin-18 in plasma and adipose tissue: effects of obesity, insulin resistance, and weight loss. Eur J Endocrinol 2007, 157:465-471.

37. Evans J, Collins M, Jennings C, Merwe van der L, Soderstrom I, Olsson T, et al: The association of interleukin-18 genotype and serum levels with metabolic risk factors for cardiovascular disease. Eur J Endocrinol 2007, 157:633-640.

38. Zirlik A, Abdullah SM, Gerdes N, MacFarlane L, Schonbeck U, Khera A, et al: Interleukin-18, the metabolic syndrome, and subclinical atherosclerosis: results from the Dallas Heart Study. Arterioscler Thromb Vasc Biol 2007, 27:2043-2049.

39. Bosch M, Lopez-Bermejo A, Vendrell J, Musri M, Ricart W, Fernandez Real JM: Circulating IL-18 concentration is associated with insulin 
sensitivity and glucose tolerance through increased fat-free mass. Diabetologia 2005, 48:1841-1843.

40. Fischer $C P$, Perstrup LB, Berntsen A, Eskildsen P, Pedersen BK: Elevated plasma interleukin-18 is a marker of insulin-resistance in type 2 diabetic and non-diabetic humans. Clin Immunol 2005, 117:152-160.

41. Straczkowski M, Kowalska I, Nikolajuk A, Otziomek E, Adamska A, KarolczukZarachowicz $M$, et al: Increased serum interleukin-18 concentration is associated with hypoadiponectinemia in obesity, independently of insulin resistance. Int J Obes (Lond) 2007, 31:221-225.

42. Rabkin SW: The role of interleukin 18 in the pathogenesis of hypertension-induced vascular disease. Nat Clin Pract Cardiovasc Med 2009, 6:192-199.

43. Van Guilder GP, Hoetzer GL, Greiner JJ, Stauffer BL, Desouza CA: Influence of metabolic syndrome on biomarkers of oxidative stress and inflammation in obese adults. Obesity (Silver Spring) 2006, 14:2127-2131.

44. He M, Cornelis MC, Kraft P, van Dam RM, Sun Q, Laurie CC, et al: GenomeWide Association Study Identifies Variants at the IL18-BCO2 Locus Associated With Interleukin-18 Levels. Arterioscler Thromb Vasc Biol 2010, 30(4):885-90.

45. Presta I, Andreozzi F, Succurro E, Marini MA, Laratta E, Lauro R, et al: IL-18 gene polymorphism and metabolic syndrome. Nutr Metab Cardiovasc Dis 2009, 19:e5-e6.

46. Aso Y, Okumura K, Takebayashi K, Wakabayashi S, Inukai T: Relationships of plasma interleukin-18 concentrations to hyperhomocysteinemia and carotid intimal-media wall thickness in patients with type 2 diabetes. Diabetes Care 2003, 26:2622-2627.

47. Esposito K, Nappo F, Giugliano F, Di PC, Ciotola M, Barbieri M, et al: Cytokine milieu tends toward inflammation in type 2 diabetes. Diabetes Care 2003, 26:1647.

48. Fujita T, Ogihara N, Kamura Y, Satomura A, Fuke Y, Shimizu C, et al: Interleukin-18 contributes more closely to the progression of diabetic nephropathy than other diabetic complications. Acta Diabetol 2010.

49. Hivert MF, Sun Q, Shrader P, Mantzoros CS, Meigs JB, Hu FB: Circulating IL18 and the risk of type 2 diabetes in women. Diabetologia 2009, 52:2101-2108.

50. Thorand B, Kolb H, Baumert J, Koenig W, Chambless L, Meisinger C, et al: Elevated levels of interleukin-18 predict the development of type 2 diabetes: results from the MONICA/KORA Augsburg Study, 1984-2002. Diabetes 2005, 54:2932-2938.

51. Esposito K, Nappo F, Marfella R, Giugliano G, Giugliano F, Ciotola M, et al: Inflammatory cytokine concentrations are acutely increased by hyperglycemia in humans: role of oxidative stress. Circulation 2002, 106:2067-2072.

52. Yamagami H, Kitagawa K, Hoshi T, Furukado S, Hougaku H, Nagai Y, et al: Associations of serum IL-18 levels with carotid intima-media thickness. Arterioscler Thromb Vasc Biol 2005, 25:1458-1462.

53. Chapman CM, McQuillan BM, Beilby JP, Thompson PL, Hung J: Interleukin18 levels are not associated with subclinical carotid atherosclerosis in a community population. The Perth Carotid Ultrasound Disease Assessment Study (CUDAS). Atherosclerosis 2006, 189:414-419.

54. Nakamura A, Shikata K, Hiramatsu M, Nakatou T, Kitamura T, Wada J, et al Serum interleukin-18 levels are associated with nephropathy and atherosclerosis in Japanese patients with type 2 diabetes. Diabetes Care 2005, 28:2890-2895.

55. Troseid M, Seljeflot I, Weiss TW, Klemsdal TO, Hjerkinn EM, Arnesen H: Arterial stiffness is independently associated with interleukin-18 and components of the metabolic syndrome. Atherosclerosis 2009.

56. Blankenberg S, Tiret L, Bickel C, Peetz D, Cambien F, Meyer J, et al: Interleukin-18 is a strong predictor of cardiovascular death in stable and unstable angina. Circulation 2002, 106:24-30.

57. Tiret L, Godefroy T, Lubos E, Nicaud V, Tregouet DA, Barbaux S, et al: Genetic analysis of the interleukin-18 system highlights the role of the interleukin-18 gene in cardiovascular disease. Circulation 2005, 112:643-650.

58. Blankenberg S, Luc G, Ducimetiere P, Arveiler D, Ferrieres J, Amouyel P, et al: Interleukin-18 and the risk of coronary heart disease in European men: the Prospective Epidemiological Study of Myocardial Infarction (PRIME). Circulation 2003, 108:2453-2459.

59. Everett BM, Bansal S, Rifai N, Buring JE, Ridker PM: Interleukin-18 and the risk of future cardiovascular disease among initially healthy women. Atherosclerosis 2009, 202:282-288.
60. Koenig W, Khuseyinova N, Baumert J, Thorand B, Loewel H, Chambless L, et al: Increased concentrations of C-reactive protein and IL- 6 but not IL18 are independently associated with incident coronary events in middle-aged men and women: results from the MONICA/KORA Augsburg case-cohort study, 1984-2002. Arterioscler Thromb Vasc Biol 2006, 26:2745-2751.

61. Grisoni ML, Proust C, Alanne M, Desuremain M, Salomaa V, Kuulasmaa K, et al: Lack of association between polymorphisms of the IL18R1 and IL18RAP genes and cardiovascular risk: the MORGAM Project. BMC Med Genet 2009, 10:44.

62. Espinola-Klein C, Rupprecht HJ, Bickel C, Lackner K, Genth-Zotz S, Post F, et al: Impact of inflammatory markers on cardiovascular mortality in patients with metabolic syndrome. Eur I Cardiovasc Prev Rehabil 2008, 15:278-284.

63. Troseid M, Seljeflot I, Hjerkinn EM, Arnesen H: Interleukin-18 is a strong predictor of cardiovascular events in elderly men with the metabolic syndrome: synergistic effect of inflammation and hyperglycemia. Diabetes Care 2009, 32:486-492.

64. Mallat Z, Corbaz A, Scoazec A, Besnard S, Leseche G, Chvatchko Y, et al: Expression of interleukin-18 in human atherosclerotic plaques and relation to plaque instability. Circulation 2001, 104:1598-1603.

65. Robertson AK, Hansson GK: T cells in atherogenesis: for better or for worse? Arterioscler Thromb Vasc Biol 2006, 26:2421-2432.

66. Leon ML, Zuckerman SH: Gamma interferon: a central mediator in atherosclerosis. Inflamm Res 2005, 54:395-411.

67. de Nooijer R, Thusen von der JH, Verkleij CJ, Kuiper J, Jukema JW, Wall van der EE, et al: Overexpression of IL-18 decreases intimal collagen content and promotes a vulnerable plaque phenotype in apolipoprotein-Edeficient mice. Arterioscler Thromb Vasc Biol 2004, 24:2313-2319.

68. Woldbaek PR, Tonnessen T, Henriksen UL, Florholmen G, Lunde PK, Lyberg T, et al: Increased cardiac IL-18 mRNA, pro-IL-18 and plasma IL-18 after myocardial infarction in the mouse; a potential role in cardiac dysfunction. Cardiovasc Res 2003, 59:122-131.

69. Tan HW, Liu X, Bi XP, Xing SS, Li L, Gong HP, et al: IL-18 overexpression promotes vascular inflammation and remodeling in a rat model of metabolic syndrome. Atherosclerosis 2010, 208:350-357.

70. Despres JP, Lemieux I, Bergeron J, Pibarot P, Mathieu P, Larose E, et al: Abdominal obesity and the metabolic syndrome: contribution to global cardiometabolic risk. Arterioscler Thromb Vasc Biol 2008, 28:1039-1049.

71. Lau DC, Dhillon B, Yan H, Szmitko PE, Verma S: Adipokines: molecular links between obesity and atheroslcerosis. Am J Physiol Heart Circ Physiol 2005, 288: $\mathrm{H} 2031-\mathrm{H} 2041$.

72. Wood IS, Wang B, Jenkins JR, Trayhurn P: The pro-inflammatory cytokine IL-18 is expressed in human adipose tissue and strongly upregulated by TNFalpha in human adipocytes. Biochem Biophys Res Commun 2005, 337:422-429.

73. Sun J, Xu Y, Dai Z, Sun Y: Intermittent high glucose stimulate MCP-I, IL18 , and PAl-1, but inhibit adiponectin expression and secretion in adipocytes dependent of ROS. Cell Biochem Biophys 2009, 55:173-180.

74. Weisberg SP, McCann D, Desai M, Rosenbaum M, Leibel RL, Ferrante AW Jr: Obesity is associated with macrophage accumulation in adipose tissue. $J$ Clin Invest 2003, 112:1796-1808.

75. Xu H, Barnes GT, Yang Q, Tan G, Yang D, Chou CJ, et al: Chronic inflammation in fat plays a crucial role in the development of obesityrelated insulin resistance. J Clin Invest 2003, 112:1821-1830.

76. Kintscher U, Hartge M, Hess K, Foryst-Ludwig A, Clemenz M, Wabitsch M, et al: T-lymphocyte infiltration in visceral adipose tissue: a primary event in adipose tissue inflammation and the development of obesitymediated insulin resistance. Arterioscler Thromb Vasc Biol 2008, 28:1304-1310.

77. Winer S, Chan Y, Paltser G, Truong D, Tsui H, Bahrami J, et al: Normalization of obesity-associated insulin resistance through immunotherapy. Nat Med 2009, 15:921-929.

78. Wegner M, Winiarska H, Bobkiewicz-Kozlowska T, Dworacka M: IL-12 serum levels in patients with type 2 diabetes treated with sulphonylureas. Cytokine 2008, 42:312-316.

79. Wen Y, Gu J, Li SL, Reddy MA, Natarajan R, Nadler JL: Elevated glucose and diabetes promote interleukin-12 cytokine gene expression in mouse macrophages. Endocrinology 2006, 147:2518-2525.

80. Krogh-Madsen R, Plomgaard P, Moller K, Mittendorfer B, Pedersen BK: Influence of TNF-alpha and IL-6 infusions on insulin sensitivity and 
expression of IL-18 in humans. Am J Physiol Endocrinol Metab 2006, 291: E108-E114.

81. Troseid M, Lappegard KT, Mollnes TE, Arnesen H, Seljeflot I: The effect of exercise on serum levels of interleukin-18 and components of the metabolic syndrome. Metab Syndr Relat Disord 2009, 7:579-584.

82. Li YP, Reid MB: Effect of tumor necrosis factor-alpha on skeletal muscle metabolism. Curr Opin Rheumatol 2001, 13:483-487.

83. Plomgaard P, Penkowa M, Pedersen BK: Fiber type specific expression of TNF-alpha, IL-6 and IL-18 in human skeletal muscles. Exerc Immunol Rev 2005, 11:53-63.

84. Netea MG, Joosten LA, Lewis E, Jensen DR, Voshol PJ, Kullberg BJ, et al: Deficiency of interleukin-18 in mice leads to hyperphagia, obesity and insulin resistance. Nat Med 2006, 12:650-656.

85. Zilverschoon GR, Tack CJ, Joosten LA, Kullberg BJ, Meer van der JW, Netea MG: Interleukin-18 resistance in patients with obesity and type 2 diabetes mellitus. Int J Obes (Lond) 2008, 32:1407-1414.

86. Delamaire M, Maugendre D, Moreno M, Le Goff MC, Allannic H, Genetet B: Impaired leucocyte functions in diabetic patients. Diabet Med 1997, 14:29-34.

87. Gallacher SJ, Thomson G, Fraser WD, Fisher BM, Gemmell CG, MacCuish AC: Neutrophil bactericidal function in diabetes mellitus: evidence for association with blood glucose control. Diabet Med 1995, 12:916-920.

88. Tsiavou A, Hatziagelaki E, Chaidaroglou A, Koniavitou K, Degiannis D, Raptis SA: Correlation between intracellular interferon-gamma (IFNgamma) production by CD4+ and CD8+ lymphocytes and IFN-gamma gene polymorphism in patients with type 2 diabetes mellitus and latent autoimmune diabetes of adults (LADA). Cytokine 2005, 31:135-141.

89. Anderssen SA, Carroll S, Urdal P, Holme I: Combined diet and exercise intervention reverses the metabolic syndrome in middle-aged males: results from the Oslo Diet and Exercise Study. Scand I Med Sci Sports 2007, 17:687-695.

90. Tuomilehto J, Lindstrom J, Eriksson JG, Valle TT, Hamalainen H, llanneParikka $P$, et al: Prevention of type 2 diabetes mellitus by changes in lifestyle among subjects with impaired glucose tolerance. $N$ Engl I Med 2001, 344:1343-1350.

91. Esposito K, Pontillo A, Ciotola M, Di Palo C, Grella E, Nicoletti G, et al: Weight loss reduces interleukin-18 levels in obese women. $J$ Clin Endocrinol Metab 2002, 87:3864-3866.

92. Esposito K, Pontillo A, Di Palo C, Giugliano G, Masella M, Marfella R, et al: Effect of weight loss and lifestyle changes on vascular inflammatory markers in obese women: a randomized trial. JAMA 2003, 289:1799-1804.

93. Troseid $M$, Arnesen $H$, Hjerkinn EM, Seljeflot I: Serum levels of interleukin18 are reduced by diet and $n-3$ fatty acid intervention in elderly highrisk men. Metabolism 2009, 58:1543-1549.

94. Esposito K, Marfella R, Ciotola M, Di Palo C, Giugliano F, Giugliano G, et al: Effect of a mediterranean-style diet on endothelial dysfunction and markers of vascular inflammation in the metabolic syndrome: a randomized trial. JAMA 2004, 292:1440-1446.

95. Kadoglou NP, lliadis F, Angelopoulou N, Perrea D, Ampatzidis G, Liapis CD, et al: The anti-inflammatory effects of exercise training in patients with type 2 diabetes mellitus. Eur J Cardiovasc Prev Rehabil 2007, 14:837-843.

96. Kadoglou NP, lliadis F, Sailer N, Athanasiadou Z, Vitta I, Kapelouzou A, et al: Exercise training ameliorates the effects of rosiglitazone on traditional and novel cardiovascular risk factors in patients with type 2 diabetes mellitus. Metabolism 2009, 59(4):599-607.

97. Kohut ML, McCann DA, Russell DW, Konopka DN, Cunnick JE, Franke WD, et al: Aerobic exercise, but not flexibility/resistance exercise, reduces serum IL-18, CRP, and IL- 6 independent of beta-blockers, BMI, and psychosocial factors in older adults. Brain Behav Immun 2006, 20:201-209.

98. Lindegaard B, Hansen T, Hvid T, van HG, Plomgaard P, Ditlevsen S, et al: The effect of strength and endurance training on insulin sensitivity and fat distribution in human immunodeficiency virus-infected patients with lipodystrophy. J Clin Endocrinol Metab 2008, 93:3860-3869.

99. Leick L, Lindegaard B, Stensvold D, Plomgaard P, Saltin B, Pilegaard H: Adipose tissue interleukin-18 mRNA and plasma interleukin-18: effect of obesity and exercise. Obesity (Silver Spring) 2007, 15:356-363.

100. Leu HB, Chen JW, Wu TC, Ding YA, Lin SJ, Charng MJ: Effects of fluvastatin, an HMG-CoA reductase inhibitor, on serum levels of interleukin-18 and matrix metalloproteinase-9 in patients with hypercholesterolemia. Clin Cardiol 2005, 28:423-428.
101. Yamagami H, Sakaguchi M, Furukado S, Hoshi T, Abe Y, Hougaku H, et al: Statin therapy increases carotid plaque echogenicity in hypercholesterolemic patients. Ultrasound Med Biol 2008, 34:1353-1359.

102. Baldassarre D, Porta B, Camera M, Amato M, Arquati M, Brusoni B, et al: Markers of inflammation, thrombosis and endothelial activation correlate with carotid IMT regression in stable coronary disease after atorvastatin treatment. Nutr Metab Cardiovasc Dis 2009, 19:481-490.

103. Coward WR, Marei A, Yang A, Vasa-Nicotera MM, Chow SC: Statin-induced proinflammatory response in mitogen-activated peripheral blood mononuclear cells through the activation of caspase-1 and IL-18 secretion in monocytes. J Immunol 2006, 176:5284-5292.

104. Montero MT, Hernandez O, Suarez Y, Matilla J, Ferruelo AJ, Martinez-Botas J, et al: Hydroxymethylglutaryl-coenzyme A reductase inhibition stimulates caspase-1 activity and Th1-cytokine release in peripheral blood mononuclear cells. Atherosclerosis 2000, 153:303-313.

105. Takahashi HK, Mori S, Iwagaki H, Yoshino T, Tanaka N, Nishibori M: Simvastatin induces interleukin-18 production in human peripheral blood mononuclear cells. Clin Immunol 2005, 116:211-216.

106. Sahar S, Dwarakanath RS, Reddy MA, Lanting L, Todorov I, Natarajan R: Angiotensin II enhances interleukin-18 mediated inflammatory gene expression in vascular smooth muscle cells: a novel cross-talk in the pathogenesis of atherosclerosis. Circ Res 2005, 96:1064-1071.

107. Doi T, Sakoda T, Akagami T, Naka T, Mori Y, Tsujino T, et al: Aldosterone induces interleukin-18 through endothelin-1, angiotensin II, Rho/Rhokinase, and PPARs in cardiomyocytes. Am J Physiol Heart Circ Physiol 2008, 295:H1279-H1287.

108. White M, Lepage S, Lavoie J, De DS, Leblanc MH, Gossard D, et al: Effects of combined candesartan and ACE inhibitors on BNP, markers of inflammation and oxidative stress, and glucose regulation in patients with symptomatic heart failure. J Card Fail 2007, 13:86-94.

109. Wang M, Markel TA, Meldrum DR: Interleukin 18 in the heart. Shock 2008, 30:3-10.

doi:10.1186/1475-2840-9-11

Cite this article as: Trøseid et al:: The role of interleukin-18 in the metabolic syndrome. Cardiovascular Diabetology 2010 9:11.

\section{Submit your next manuscript to BioMed Central and take full advantage of:}

- Convenient online submission

- Thorough peer review

- No space constraints or color figure charges

- Immediate publication on acceptance

- Inclusion in PubMed, CAS, Scopus and Google Scholar

- Research which is freely available for redistribution

Submit your manuscript at www.biomedcentral.com/submit
C Biomed Central 